\title{
Fiscal and Monetary Policies and the Cost of Sudden Stops*
}

\author{
by Michael M. Hutchison, \\ Department of Economics, \\ University of California, Santa Cruz \\ Ilan Noy ${ }^{\dagger}$, \\ Department of Economics, \\ University of Hawaii, Manoa \\ Lidan Wang, \\ Risk Management, \\ HSBC Credit Card Services
}

Working Paper No. 07-24

July 17, 2007

\begin{abstract}
This article investigates the effects of macroeconomic policy (monetary and fiscal) on output growth during financial crises characterized by a "sudden stop" in net capital inflows in developing and emerging market economies. We investigate 83 sudden stop crises in 77 countries over 1982-2003 using a baseline empirical model to control for the various determinants of output losses during sudden stop crises. Extending the baseline model to account for policies-- contractionary as well as expansionary-- we measure the marginal effects of policy on output losses. Simple descriptive statistics indicate no apparent correlation between the costs of financial crises and the economic policies pursed at the time. Once controlling for various preconditions and other factors, however, we find that monetary and fiscal tightening at the time of a sudden stop crisis significantly worsens output losses.
\end{abstract}

Key Words: Output losses, financial crises, sudden stops, fiscal policy, financial policy

JEL Codes: E52, E62, F32, F43, O16

\footnotetext{
${ }^{*}$ We thank Eduardo Cavallo, Menzie Chinn, Adam Honig, and Hiro Ito for providing us with data.

${ }^{\dagger}$ Corresponding author.
} 


\section{Introduction}

The "sudden stop" of international capital inflows to developing and emerging market economies has become a major disruptive factor in several recent financial crises. The suddenstop problem features an abrupt cessation in foreign capital inflows and/or sharp capital outflows leading to a balance of payments crisis. A growing literature suggests that the collapse of investment and financial intermediation resulting from sudden stops is the main component of the very dramatic output collapses that have periodically hit many developing and emerging market economies. More than one hundred sudden stops in capital inflows may be identified over the past twenty-five years, with an average output loss by one measure approaching almost 10 percent of GDP. ${ }^{1}$

Calvo et al. (2002), for example, provide a sudden-stop interpretation for the recent crisis in Argentina in which the capital flow reversal together with dramatic real exchange rate depreciation significantly worsened the government's fiscal position, led to a debt default, and an output collapse. Hutchison and Noy (2006) show that sudden stops have severe consequences for the economy, as the abrupt reversal in foreign credit inflows in conjunction with a realignment of the exchange rate typically cause a sharp drop in domestic investment, domestic production and employment. In a broader historical examination, Bordo et al. (2001) argue that the sudden stop problem has become more severe since the abandonment of the gold standard in the early 1970 s.

The IMF financial assistance programs signed by Thailand, Korea, and Indonesia during the 1997-98 Asian financial crisis generated a very heated debate about the best use of fiscal and monetary policies during a crisis situation. The IMF policy recommendation, which were incorporated as an integral part of the conditionality agreements in their loan packages, called for fiscal and monetary tightening. This was articulated clearly by the IMF First Deputy Managing 
Director at the time, Stanley Fischer. One of the most prominent critics of this prescription was Joseph Stiglitz, then Senior Vice President and Chief Economist of the World Bank. This public disagreement on such a key policy issue among the leading economists at the two major Bretton Woods institutions is unprecedented.

Fischer argues that the prescription of tight fiscal and monetary policy is justified by the fact that the governments that entered a crisis usually face large budget deficits and high inflation. When describing Thailand, Indonesia and Korea, Fischer writes that: "The macroeconomic parts of these programs consist of a combination of tight money to restore confidence in the currency and a modest firming up of fiscal policy to offset in part the massive costs of financial restructuring." (Fischer, 1998, p. 103). Providing further detail, he writes: "On the appropriate degree of fiscal tightening, the balance is a particularly fine one. At the onset of the crisis, countries needed to firm up their finances, both to cover the costs of financial restructuring, and - depending on the balance-of-payments situation — to reduce their current account deficits, which depend in part on the budget deficit." (Fischer, 1998, p. 105).

Stiglitz, by contrast, agrees that the key monetary component is restoring confidence but argues that confidence arises out of a good macroeconomic environment and not tight policies in the midst of a financial crisis. A healthy growth rate is the best indicator, in his view, to bolster confidence and a prescription of tight money and high interest rates will do exactly the opposite. He notes that “...maintaining tight monetary policies has led to interest rates that would make job creation impossible even in the best of circumstances" (Stiglitz, 2002, p. 17). Thus, by making the recession even deeper, the policy ends up reducing confidence in the economy rather than enhancing it. Stiglitz terms this the 'beggar-thyself' policy (Stiglitz 1999a, 1999b). Regarding the Asian financial crisis, he writes: “...contractionary fiscal and monetary policies combined with 
misguided financial policies led to massive economic downturns, cutting incomes, which reduced imports and led to huge trade surpluses, giving the countries the resources to pay back foreign creditors." (Stiglitz, 2002, p. 107-8).

To date there is no professional consensus, based on theory or empirical studies, on which approach is more conducive to achieving growth targets following a sudden stop in capital inflows. Aghion et al. (2004) and Lahiri and Végh (2007), for example, in theoretical papers, examine the impact of monetary policy on currency crises and conclude that contractionary monetary policy (an interest rate defense) might result in greater output contraction. ${ }^{2}$ In contrast, Christiano et al. (2004) conclude from their theoretical work that when there are frictions in adjustment in the traded goods sector, an expansionary monetary policy during a financial crisis might be welfare reducing. Similarly, Céspedes et al. (2004) and Cúrdia (2007) look at exchange rate policy during currency crises and conclude that a flexible regime is Pareto superior. ${ }^{3}$ Razin and Sadka (2004) offer an analysis of fiscal policy in a debt crisis and describe the conditions under which increasing the budget surplus might not help even if the original trigger for the crisis was government debt; while Mitra (2006) introduces an equivalent examination and concludes that the impact of fiscal policy on the growth outcome depends on the flexibility of production.

Little empirical work has addressed the optimal policy response to a financial crisis. This paper attempts to fill this gap in the literature. In particular, we consider "sudden stop" financial crises and investigate the wide range of monetary, fiscal and exchange rate policy responses to 83 crises that have been occurred over 1980-2003 in 66 countries. The paths of economies at the time of sudden stops vary widely (Table 1), with about 65 percent of sudden stop crises followed by an output contraction, and about 35 percent of the cases followed by an output expansion. In 
the extremes, at least by one measure (defined below), output varies from cumulative output loss (relative to trend) of over 80 percent of GDP to a cumulative gain of over 20 percent of GDP.

However, it is not clear what factors, and especially which government policies, have contributed to the wide diversity of outcomes. Some examples illustrate this point. During the 1982 Latin American crisis, Bolivia sharply contracted both money and fiscal policy, while Chile held monetary policy steady and only instituted a mildly contractionary fiscal policy. Both countries, however, experienced sharp declines in output-- Bolivia on the order of $24 \%$ of GDP and Chile around 28\% of GDP. In response to sudden stops, Malaysia pursued a fiscal expansion and no contraction in monetary policy (1997) while Venezuela pursued a monetary expansion and a steady fiscal policy (1994). Both countries, despite the differences in their policy responses, experienced significant output declines.

Moreover, it is not even obvious from casual observation of the aggregate data how policies are linked to output losses during sudden stops. The top panel of Table 1 shows the number of observations (frequencies) associated with output contraction and expansion, in the columns, against observations of fiscal contraction and expansion in the rows. (Although we have 83 cases of sudden stops in the sample, we only have fiscal data for 64 cases). About 2/3 of sudden stops are associated with output contractions. Of the 44 episodes of output contraction during sudden stops, 17 were associated with fiscal contraction and 27 with fiscal expansion. Of the 20 cases associated with output expansion, 8 cases were associated with fiscal contraction and 12 cases with fiscal expansion. Similarly, no simple story is apparent from monetary policy responses, shown in Table 1. The great majority of cases of either output contraction or output expansion were not associated with a significant change in monetary policy ( 73 percent and 89 percent, respectively). Monetary contractions were only followed in about 9 percent of sudden 
stop episodes, and expansionary policy in about 13 percent of the cases. Only 5 episodes of the cases with output declined were associated with monetary contractions, and a similar percentage of monetary contractions were followed when output expanded during sudden stop episodes.

The summary statistics reported in Table 1, and illustrative cases discussed above, suggest that a number of factors, working simultaneously, have influenced the evolution of output following sudden stop crises. Our objective is to investigate the effects of macroeconomic policies on the path of output following sudden stops while controlling for a host of variables that are also likely to play an important role. No study to date has explored this issue using a broad range of crisis experiences. Rather, the extant literature typically considers a series of case studies. These provide very valuable insights but it is difficult to derive general conclusions. In our work we focus on sudden stops, since these are the crises that have been most costly and the response to them the most controversial. The central issue we address is the optimal macroeconomic policy response to a sudden stop crisis. We consider the effectiveness of monetary and fiscal policy responses, as well as various combinations of policy responses, in mitigating the output losses usually associated with financial crises. We employ regression methods in our empirical investigations (cross section of sudden stop crisis episodes) to control for the wide variety of factors potentially affecting output paths of economies, and formally test several hypotheses on the effects of contractionary (expansionary) macroeconomic policy responses to financial crises. On balance, we find support for the view that contractionary monetary and fiscal policies during a financial crisis exacerbate the economic downturn.

Section 2 reviews the literature on sudden stops and highlights our contribution. Section 3 presents the basic empirical model. Section 4 discusses the data employed in the study, and 
section 5 reports summary statistics on key macroeconomic variables and the primary empirical results of the study. Section 6 concludes.

2. Why should a sudden top cause a collapse in output?

Recent theoretical literature, following the pioneering work of Calvo (1998) and Calvo and Reinhart (2000), emphasizes the linkage between sudden stops and output losses. Calvo (1998, 2000) and Calvo and Reinhart (2000) analyze several channels through which a sudden stop in international capital flows may bring about a currency and balance of payments crisis and, subsequently, an output collapse. One mechanism may be termed the traditional Keynesian effect whereby a fall in credit, attributable to the sudden stop in capital inflows, combined with an external financing premium and a "financial accelerator," reduces aggregate demand and causes a fall in output (e.g. Bernanke et al., 1999). Furthermore, firm bankruptcies may cause negative externalities-- banks may become more cautious and reduce loans. This in turn may induce a further fall in credit - the "vanishing credit effect" described in Calvo (2000)--and exacerbate an output decline.

Another mechanism, termed the Fisherian debt-deflation channel by Mendoza (2001), emphasizes that a sudden stop, given collateral constraints, might induce margin calls, a sell-off of assets and consequently a contraction of credit and output (e.g., Kiyotaki and Moore, 1997, 2001, and Mendoza and Smith, 2006). ${ }^{4}$ In these frameworks, even though the government sector is typically not modeled, it is likely that a Keynesian prescription of expanding demand through expansionary fiscal and monetary policies would reduce the severity of a sudden stop crisis. A third possible channel focuses on the contract enforceability/moral hazard problem as described in Schneider and Tornell (2004) and the search friction model of Gopinath (2004). Moreover, 
Caballero and Krishnamurthy (2002 and 2004), Durdu and Mendoza (2006), and others develop models that suggest changes in the global financial architecture might lead to the prevention of sudden stops or to lowering their costs.

Until recently, however, most empirical literature has not clearly distinguished between the different types of financial crises. Kaminsky (2006) sets out a crisis classification scheme and demonstrates that sudden stops are a special variety of financial crises. She argues that a sudden stop, in the sense of a capital inflow reversal in tandem with a currency/balance of payments crisis, is a special type of currency crisis. Using a regression-tree classification methodology, she finds that the set of explanatory factors associated with sudden stop special crises are different than other financial crises. Honig (2005), Calvo et al. (2004 and 2006), Cavallo and Frankel (2005) and others also empirically examine the factors explaining the occurrence of sudden stops. Several recent papers empirically analyze output developments around the time of banking or currency crises in broad samples of countries, e.g. Aziz et al. (2000), Barro (2001), Bordo et al. (2001), Gupta et al. (2007), Hutchison and McGill (1999), Hutchison and Noy $(2002,2005)$ and Frankel (2005).

The empirical finding that the causes of sudden stops differ from currency, banking and "twin" (joint currency and banking) crises suggest that the effects on the real economy are also likely to be different. Indeed, Hutchison and Noy (2006), in a large panel of countries over time, find that the costs of sudden stops are much higher than those for other types of financial crisis. Becker and Mauro (2006) also identify episodes of output collapse ('output drops') and empirically associate those with the occurrence of sudden stops. Bordo et al. (2001), MilesiFerretti and Razin (2000) and Edwards (2004) focus on the determinants of the costs of crises, 
emphasizing the effect of structural factors such as trade openness, the size of the preceding current account deficit and the exchange rate regime.

However, no paper that we are aware has attempted to empirically measure the impact on output of the ex-post policy macroeconomic policy decisions taken in response to a sudden stop.

3. Estimating the effects of policies on the output costs of sudden stops

The first step in the analysis is to set out a benchmark model that attempts to explain output costs following a sudden stop financial crisis by a standard set of variables. Our observational units are a cross-section of sudden stop episodes (98 in total) and the question we address is, given the occurrence of a sudden stop, what variables and policies appear to influence its severity in terms of output losses. The benchmark output cost model introduce relevant control variables into the regression equation, allowing us to identify the marginal effects of macroeconomic policy and limit potential omitted-variables bias. The controls are from a broad set of variables identified in the literature as important determinants of the output cost of financial crises (see appendix).

In the context of our benchmark model, we test for the additional effect of fiscal, monetary and exchange rate policies on output growth following a sudden stop (we discuss the definitions of the policy variables in section 4).

The formal specification of the empirical model is as follows:

$\operatorname{Cost}_{i}=\alpha+\beta_{k} \boldsymbol{X}_{i}+\beta_{1} \Delta_{i}{ }^{\text {fis }}+\beta_{2} D_{i}^{\text {mon }}+\beta_{3} D_{i}^{\text {exr }}+\varepsilon_{i}$

Where Cost is the cost of the sudden stop $i$ in terms of forgone output (deviations from trend output growth), $\boldsymbol{X}$ is a vector of control variables, $\Delta^{\text {fis }}$ is the change in discretionary fiscal policy, and $D^{x}$ are binary indicators of policy $x \quad(1=$ expansionary/contractionary, $0=$ not 
expansionary/contractionary) for monetary expansion, monetary contraction, domestic exchange rate support operations (international reserve de-cumulation), and foreign exchange rate support operations (international reserve accumulation). We construct our fiscal and monetary policy variables so as to limit the likelihood that reverse causality (from output losses to policy changes) will bias our estimates. In particular, we measure only the discretionary part of fiscal policy (derived from country-specific measures of fiscal stance over time) and construct binary indicators for discrete changes in monetary policy stance. This is described in the next section. The cross-sectional methodology we employ is also less susceptible to some of the simultaneity issues more pervasive in dynamic panel and time series analyses.

\section{Data description}

We focus on developing and emerging market countries since they are the subject of policy discussions and recent financial crises and output collapses. Several studies indicate that developing and emerging market countries are different from industrialized/developed countries with respect to the factors that make them susceptible to a financial crisis (Broner and Rigobon, 2006; Glick and Hutchison, 2005; Caballero and Krishnamurthy, 2002; and Tornell and Westermann 2002). Specifically, these countries tend to be especially open to international capital inflows that are short-term in nature and usually denominated in foreign-currency ("original sin") in the terminology of Eichengreen and Hausman, 2005). These characteristics increase the vulnerability of developing and emerging-market economies to swings in exchange rates and cessation of new capital to roll over expiring debt.

\section{Defining the output cost measures}


There is no single commonly accepted methodology to measure the output costs of a crisis or, for that matter, the foregone output costs associated with a more generic economic recession. For this reason we use three alternative measures of output cost in our empirical analysis to test the robustness of our results.

Our benchmark measure is based on a methodology developed by researchers at the International Monetary Fund. The benchmark output loss measure (OC1) is constructed by comparing, in real terms, the pre-crisis GDP growth rate of a given country with the GDP growth rate during the subsequent years until the return to the pre-crisis rate of growth. The pre-crisis GDP growth is calculated as the average of GDP growth rates from year $t-3$ to $t-1$, where year $t$ is the start of the crisis. (Windows are imposed such that only sudden stop episodes preceded by "tranquil periods", i.e. pre-crisis periods without a sudden stop, are included in the sample.) Each GDP growth rate from year $t$ onwards is then compared to the trend until the trend growth is reached. The output loss is defined as the sum of the difference between the actual and the trend growth rate over all the years until the trend growth is reached again. ${ }^{5}$

Our second output cost measure (OC2) measures the end of the crisis as three years after the original capital flow reversal. The output cost is then constructed as the difference between the real GDP growth rate in the sudden stop episode (years $t$ to $t+2$ ) and the pre-crisis GDP growth rate (years $t-3$ to $t-1$ ). Our third measure (OC3) assumes that the crisis continues for two years and the output cost is constructed as the difference between the average real GDP growth rate in years $t$ and $t+1$ and the pre-crisis GDP growth rate (years $t-3$ to $t-1$ ).

\section{Defining Sudden Stops}


Calvo et al. (2004) and Cavallo and Frankel (2005) define sudden stops as any countryyear in which three conditions are met: (1) there is a significant reversal of capital inflows (a decrease in the financial account of at least 2 standard deviations below the country-specific sample mean), (2) any reduction in the current account deficit in either year $t$ or in $t+1$, and (3) a fall in per capita GDP (of any amount). Hutchison and Noy (2006) define a sudden-stop crisis as one in which there is the contemporaneous occurrence of a currency crisis and a current account reversal (a change in the current account of more than 3\% of GDP) while Jeanne and Rancier (2006) use a somewhat similar definition identifying a sudden stop episode as one in which there is a change in the capital account of more than $5 \%$ of GDP).

The latter two alternatives use more arbitrary thresholds, and so, in our study, we follow Honig (2005) in using the first two conditions in the Calvo et al. (2004) algorithm, but excluding the third condition - the output contraction requirement. ${ }^{6}$ Thus, a sudden stop crisis is defined as a year in which the financial account decreases by at least 2 standard deviations, while the current account surplus increases (at years $t$ or $t+1$ and by any amount).

\section{Defining fiscal policy measures}

We are interested in the discretionary fiscal policy response to a sudden-stop crisis, and not in the automatic fiscal stabilizers to a decline in output. For this reason, we need to decompose the fiscal accounts into their structural and cyclical components. The empirical literature on alternative measures of fiscal policy stance is large and somewhat controversial (see Blanchard, 1990). We employ a standard measure that attempts to measure discretionary fiscal policy by extracting both trend and cyclical measures from the budget balance, allowing us in 
turn to derive changes in the discretionary fiscal stance. Specifically, discretionary fiscal policy is measured as the estimated residual for each country over time from the following equation :

$$
B B_{t}=\beta_{0}+\alpha_{1} y_{t}+\alpha_{2} y_{t-1}+\beta_{1}+\mu_{t}
$$

Where $B B_{t}$ is budget balance (percent of GDP) of a particular country in the sample, $y$ is the real GDP growth rate for the country, " $t$ " is the time trend, and $\mu$ is the random error term. The change in discretionary fiscal policy for country $i$ is defined as

$\Delta_{i}^{f i s}=\hat{\mu}_{t}-\hat{\mu}_{t-1}$

where $\hat{\mu}_{t}$ is the estimated error term from equation (2). This measure of the change in fiscal stance is constructed to be independent of output movements and avoids simultaneity bias in our estimates of equation (1).

In the cases that the parameter estimates are not statistically significant at the $10 \%$ significance level, we apply the following decision rules. For countries with less than 5 observations for $\mathrm{BB}$ data, we run the regression with just a constant, i.e. no trend or cyclical component. For countries with more than 5 but less than 10 observations, we run the regression with constant and time trend term. For countries with more than 10 observations, we initially run the regression with a constant, time trend and a cyclical component, and then drop the cyclical variable if it is insignificant while keeping the constant and time trend.

\section{Defining monetary policy measures}

Monetary tightening episodes are considered as country/years in which the change in the monthly discount rate exceeds two country-specific standard deviations above the countryspecific mean. This follows the practice in the empirical literature that examines the effects of monetary policy on the exchange rate following a financial crisis (e.g. Baig and Goldfajn, 2001, 
and Goldfajn and Gupta, 2003). The discount rate is our indicator for monetary policy primarily because it is the only interest rate measure widely available for developing and emerging market countries. Another desirable feature of the discount rate is that it is under the control of the authorities, moves infrequently, and signals discrete policy shifts. We assign the years with one or more monetary tightening months the value of 1 and 0 otherwise (i.e., $1=$ tightening, $0=$ not tightening). Monetary expansion episodes are considered as country/years in which the change in the monthly discount rate is smaller by at least two country-specific standard deviations from the country-specific mean. We assign the years with one or more monetary tightening months the value of 1 and 0 otherwise (i.e., $1=$ loosening, $0=$ not loosening).

For some country years, there is ambiguity in assigning the tightening and loosening dummies. This is because there are years during which both monetary tightening and loosening occurred in different months. In these cases, we look at the quarterly current account and financial account data to determine at which quarter the sudden stop occurred (the quarter in which current account deficit drops and financial account surplus declines). We assign the particular year as a monetary tightening (loosening) episode if discount rate during the suddenstop quarter increased (decreased). ${ }^{7,8}$

\section{Defining exchange rate policy measures}

We measure exchange rate policy as indicated by international reserve changes. Accumulating international reserves is interpreted as foreign currency support operations, and decumulating reserves as domestic currency support operations. The reserve accumulation episodes are defined as country/years in which the change in the monthly non-gold reserves exceeds two country-specific standard deviations above the country-specific mean change. We assign the 
years with one or more reserve accumulation months the value of 1 and 0 otherwise (i.e., $1=$ reserve accumulation, $0=$ otherwise). Similarly, reserve de-cumulating episodes are defined as country/years in which the change in the monthly non-gold reserves is smaller than two countryspecific standard deviations below the country-specific mean change. We assign the years with one or more reserve de-cumulating months the value of 1 , and 0 otherwise.

For some country years, we have doubts in assigning the reserve accumulation and decumulation dummies when episodes of reserve accumulation and de-cumulation occurred in the same year. In these cases, we look at the quarterly current account and financial account data (for doubt year only) to determine at which quarter the sudden stop occurred. Then we assign that year is a reserve accumulation (de-cumulation) year if the non-gold reserves during the sudden stop quarter accumulated (de-cumulated). ${ }^{9}$ In the cases that the quarterly data is not available, we compare the first 3-month non-gold reserves with the last 3-month non-gold reserves. We assign that year is a reserve accumulation (de-cumulation) year if the non-gold reserves during the sudden stop quarter accumulated (de-cumulated). ${ }^{10}$

\section{Control variables}

The list of control variables we use in the multivariate regressions is guided by previous research (summarized in section 2) and our concerned over omitted-variables bias. We include variables in the regressions that the extant empirical literature has shown to have influenced the magnitude of the output cost associated with sudden stops. This is important since we want control for factors, other than monetary/fiscal/exchange rate policies that are likely to influence the output path of a sudden-stop episode. We use the following variables: (1) liability (deposit) dollarization per nominal GDP; (2) An index of the degree of openness of the capital account; (3) 
trade openness (the sum of exports and imports as percent of GDP); (4) a binary indicator of banking crises; (5) inflation (the average of 3 pre-crisis years' inflation to proxy for general macroeconomic stability); and (6) an index of the de facto exchange rate regime. ${ }^{11}$ The exact definitions and sources for these variables are provided in the data appendix.

\section{Empirical Results}

Descriptive statistics on sudden stops, fiscal, monetary and exchange Policies

Table 2 reports the frequencies of sudden stop events. The number of sudden stops jumped markedly between the decades of the 1980s and 1990s, and climbed further in the first few years of this decade (2000-2003). Among the developing and emerging market countries, perhaps unsurprisingly, Latin America experienced episodes of sudden stops in capital inflows most often.

Table 3 reports descriptive statistics on the output measures and the control variables (policy measures are shown in Table 1). We note that the three output measures yield different measures but their correlation is very high $(0.68-0.84)$. The average cumulative output loss ranges from around $1.4 \%$ to $9.2 \%$, depending on the measure employed, with large standard deviations that reflect a substantial range of experience. For the control variables, table 3 provides summary statistics, across the cross-section of sudden-stop episodes, for liability dollarization $(D L D)$, the de-facto exchange rate regime (DEFCTO), the degree of openness of the capital account (KAOPEN), a trade openness index (TRADE), the inflation rate (INFL), and the percentage of sudden stop crises accompanied by major banking crises (MAJ.)

Table 3 shows that the average pre-crisis inflation rate for countries experiencing sudden stops was $26 \%$ (INFL), and $19 \%$ of these episodes were accompanied by major banking crises 
$(M A J)$. In addition, the average amount of foreign-currency liabilities ( $D L D$, as a percent of GDP) at the time of sudden-stop episodes was $13 \%$, but ranged from $0 \%$ to $222 \%$. Average trade openness (TRADE) was over $80 \%$ of GDP (sum of imports and exports) at the point of the sudden stop, while capital market openness was appreciably lower-averaging -0.25 on an index ranging over the sample from -1.84 to 2.52 (high values indicate greater capital account openness). In terms of exchange rate regimes at the time of sudden stops (DEFCTO), countries on average has a high degree of rigidity (measuring 3.7 on a scale ranging from 1 to 5 , with high values indicating rigidity approximately fixed rate regimes).

\section{Benchmark model estimates}

Table 4 presents estimates of equation (1) using the benchmark measure of output costs (OC1). A negative value indicates a loss of output (cost), so that a positive (negative) coefficient on an explanatory variable implies that the variable decreases (increases) the cost of a crisis. In this set of specifications, our sudden stop crises sample is constructed based on the Honig (2005) criteria which allows (at most) 83 crisis observations. In the set of regressions described in table 4 , only the policy indicators are included as explanatory variables.

In equation 4.1 we include only the monetary policy variables and in equations 4.2 and 4.3, respectively, only include the fiscal and exchange policy variables. In column 4.1, we find evidence that monetary tightening sharply increases the cost of a sudden stops (by 10 percentage points), significant at the $10 \%$ level, while the impact of a monetary expansion is not significantly different from zero (though the coefficient is positive). In equation 4.2 , the coefficient estimate indicates that contractionary fiscal policy also sharply increases output costs, and the coefficient is also statistically significant at the $10 \%$ level. However, we find no 
statistically observable effect for exchange policy (reserve accumulation/decumulation) in equation 4.3. Both fiscal and monetary variables are included in equation 4.4. This specification again indicates a strong link between monetary and fiscal contractions and the output costs of sudden stops. This finding is once again confirmed in equation 4.5 where all three policy measures (monetary, fiscal and international reserves) are included.

Table 5 includes the policy variables with the control variables discussed in the previous section. Equation 5.1 includes only the control variables-- de-facto exchange rate regime, liability dollarization, capital account openness measure, trade openness, banking crises and inflation. The only significant determinant of output cost during sudden stops appears to be the joint occurrence of a major banking crisis. A banking crisis reduces cumulative output growth following a sudden stop by a full 12 percentage points.

In equation 5.2, we include the fiscal and monetary policy measures. Fiscal contractions again have a clear negative effect on output costs and are statistically significant. Monetary contractions are also negative, but the statistical significance is reduced somewhat when the control variables are included. This is also true when we add the exchange policy measures in equations 5.3-5.4.

Table 6 includes only the contractionary-policy measures (since expansionary-policy measures were not significant) and the set of control variables, adding as well an interactive term between capital account openness and trade openness. The results presented in Table 6 are consistent with earlier findings and equation 6.3 is especially noteworthy-all of the contractionary policy variables demonstrate statistically significant and economically important adverse effects on the economy in assessing the output cost of a sudden stop. In particular, the results indicate that an increase of the discount rate (of more than two standard deviations) will 
increase the output losses following a sudden stop by at least 10 percentage points. We also find a more modest and less robust adverse impact of fiscal tightening; and a bigger ( 7 percentage points) adverse effect of a move to support the exchange rate by selling off international reserves.

\section{Robustness tests}

In order to evaluate the robustness of our results, we estimated the basic specifications shown in Tables 4-6 using our alternative measures for output cost (OC2 and OC3). The results reported above carry over to these series of regressions as well, perhaps not surprisingly given the high correlation between our three output cost measures. We do not report the results of these robustness tests for brevity.

As an additional robustness check, we re-define the fiscal policy measures as a pair of binary variables that denote expansionary/non-expansionary and contractionary/noncontractionary fiscal stances. These binary variables are constructed from the discretionary policy measure described in the data section and are equivalent to the monetary policy measures described before. The results of all our main benchmarks remain identical when using these binary fiscal measures. ${ }^{12}$

\section{Conclusions}

This article investigates the effects of macroeconomic policy (monetary and fiscal) on output growth during financial crises characterized by a "sudden stop" in net capital inflows in developing and emerging market economies. We investigate 83 sudden stop crises in 77 countries over 1982-2003 using a baseline empirical model to control for the various determinants of output losses during sudden stop crises. Extending the baseline model to account for policies-- 
contractionary as well as expansionary-- we measure the marginal effects of policy on output losses.

Simple descriptive statistics indicate no apparent correlation between the costs of financial crises and the economic policies pursed at the time. Once controlling for various preconditions and other factors, however, we find that monetary and fiscal tightening at the time of a sudden stop crisis significantly worsens output losses. In particular, the main finding of this paper is that contractionary monetary and fiscal policies in the midst of a sudden-stop financial crisis exacerbate the recessionary consequences associated with these episodes, and these adverse effects are economically large. Defending the exchange rate policy by selling off international reserves, by contrast, has little discernable effect on the output consequences of sudden stops. Contractionary macroeconomic policies during financial crises may have some value in terms of stabilizing balance of payments, and perhaps even catalyzing capital flows, but also raise output costs. This basic result is robust to different measures of output costs, different samples and after controlling for a host of variables that may influence the path of output during a sudden-stop financial crisis. 


\section{$\underline{\text { References: }}$}

Aghion, Philippe, Philippe Bacchetta and Abhijit Banerjee (2001a). "Currency Crises and Monetary Policy in an Economy with Credit Constraints”. European Economic Review, 45, 1121-1150.

Aghion, Philippe, Philippe Bacchetta and Abhijit Banerjee (2004). "A Corporate Balance-sheet Approach to Currency Crises". Journal of Economic Theory 119(1), 6-30.

Arellano, Cristina ana Enrique Mendoza (2002). "Credit Frictions and 'Sudden Stops' in Small Open Economies: An Equilibrium Business Cycle Framework for Emerging Markets Crises" NBER Working Paper 8880 (April).

Aziz, Jahangir, Francesco Caramazza and Ranil Salgado (2000). "Currency Crises: In Search of Common Elements," IMF Working Paper WP/00/67 (March).

Baig, Taimur and Ilan Goldfajn (2001). "Monetary Policy in the Aftermath of a Currency Crisis: The Case of Asia." Review of International Economics 10(1), 92-112.

Barro, Robert (2001). "Economic Growth in East Asia Before and After the Financial Crisis," NBER Working Paper 8330 (June).

Becker, Törbjörn I., and Mauro, Paolo (2006). Output Drops and the Shocks That Matter. IMF Working Paper 06/172

Bernanke, Ben, Mark Gertler and Simon Gilchrist (1999). "The Financial Accelerator in a Quantitative Business Cycle Framework". In Taylor, John and Michael Woodford (eds.) Handbook of Macroeconomics. Amsterdam, New York and Oxford: Elsevier Science, North-Holland.

Blanchard, Olivier et al. (1990). "The Sustainability of Fiscal Policy: New Answers to an Old Question," OECD Economic Studies 15, 7-36.

Bordo, Michael, Barry Eichengreen, Daniela Klingebiel and Maria Soledad Martinez-Peria (2001). "Is the Crisis Problem Growing More Severe?" Economic Policy, 16(32), April, 53-82.

Broner, Fernando A. and Roberto Rigobon (2006). Why are capital flows so much more volatile in emerging than in developed countries? In: Caballero, R., C. Calderón and L. Céspedes (eds.) External Vulnerability and Preventive Policies. Banco Central de Chile.

Durdu, Ceyhun Bora and Enrique G. Mendoza (2006). Are Asset Price Guarantees Useful for Preventing Sudden Stops? A Quantitative Investigation of the Globalization Hazard-Moral Hazard Tradeoff." Journal of International Economics 69(1), 84-119.

Caballero, Ricardo and Arvind Krishnamurthy (2002). "A Dual Liquidity Model for Emerging Markets." American Economic Review, (May).

Caballero, Ricardo and Arvind Krishnamurthy (2004). "Smoothing Sudden Stops". Journal of Economic Theory 119(1), 104-127.

Calvo, Guillermo (1998). "Capital Flows and Capital-Market Crises: The simple economics of Sudden Stops," Journal of Applied Economics, 1(1), November, 35-54. 
Calvo, Guillermo (2000). "Balance-of-Payments Crises in Emerging Markets: Large Capital Inflows and Sovereign Governments" in Krugman, Paul (ed.) Currency Crises, Chicago, Illinois: University of Chicago Press.

Calvo, Guillermo, Alejandro Izquierdo, and Ernesto Talvi (2002). Sudden Stops, the Real Exchange Rate and Fiscal Sustainability: Argentina's Lessons. Inter-American Development Bank Working Paper 469.

Calvo, Guillermo, Alejandro Izquierdo and Luis-Fernando Mejía (2004). "On the Empirics of Sudden Stops: The Relevance of Balance Sheet Effects.” NBER Working Paper 10520.

Calvo, Guillermo, Alejandro Izquierdo and Rudy Loo-Kung (2006). "Relative Price Volatility under Sudden Stops: The Relevance of Balance Sheet Effects.” Journal of International Economics 69(1), 231254.

Calvo, Guillermo and Carmen Reinhart (2000). "When Capital Inflows Come to a Sudden Stop: Consequences and Policy Options," in Peter Kenen and Alexander Swoboda (eds.) Reforming the International Monetary and Financial System, Washington D.C., The International Monetary Fund.

Céspedes, Luis P., Roberto Chang and Andrés Velasco (2004). "Balance Sheets and Exchange Rate Policy". American Economic Review 94(4), 1183-1193.

Chang, Roberto, and Andres Velasco (2000). "Financial Fragility and the Exchange Rate Regime." Journal of Economic Theory 92, 1-34.

Chari V.V., Patrick J. Kehoe, and Ellen R. McGrattan (2005). "Sudden Stops and Output Drops.” NBER Working Paper 11133.

Christiano, Lawrence, Christopher Gust, and Jorge Roldos (2004). Monetary policy in a financial crisis. Journal of Economic Theory 119 (1) 64-103.

Cúrdia, Vasco (2007). Monetary Policy under Sudden Stops. Federal Reserve Bank of New York Staff Reports, Number 278.

Edwards, Sebastian (2002). "Does the Current Account Matter?" in Preventing Currency Crises in Emerging Markets, S. Edwards and J. A. Frankel (eds.). The University of Chicago Press.

Edwards, Sebastian (2004). Thirty Years of Current Account Imbalances, Current Account Reversals And Sudden Stops.” NBER Working Paper \#10276, January.

Eichengreen, Barry and Ricardo Hausman (2005). Other People's Money: Debt Denomination and Financial Instability in Emerging Market Economies. University of Chicago Press.

Fischer, Stanley (1998). "In Defence of the IMF: Specialized Tools for a Specialized Task." Foreign Affairs 77(4), 103-107.

Frankel, Jeffrey (2005). "Contractionary Currency Crashes in Developing Countries." IMF Staff Papers 52(2), 149-192.

Frankel, Jeffrey and Andrew Rose (1996). "Currency Crashes in Emerging Markets. An Empirical Treatment," Journal of International Economics, 41, November, 351-366. 
Glick, Reuven and Michael Hutchison (2005). "Capital Controls and Exchange Rate Instability in Developing Economies," Journal of International Money and Finance 24(3), 387-412.

Glick, Reuven and Michael Hutchison (2001). "Banking and Currency Crises: How Common Are Twins?” In R. Glick, R. Moreno, and M. Spiegel (eds.) Financial Crises in Emerging Markets. Cambridge, UK: Cambridge University Press.

Goldfajn, Ilan, and Poonam Gupta (2003). "Does Monetary Policy Stabilize the Exchange Rate Following a Currency Crisis?” IMF Staff Papers 50(1), 90-114.

Gopinath, Gita (2004). "Lending Booms, Sharp Reversals and Real Exchange Rate Dynamics". Journal of International Economics 62, 1-23.

Gupta, Poonam, Deepak Mishra and Ratna Sahay (2007). "Behavior of output during currency crises," Journal of International Economics 72, 428-450.

Honig, Adam (2005). Do Improvements in Government Quality Necessarily Reduce the Incidence of Sudden Stops? Journal of Banking and Finance (forthcoming).

Hutchison, Michael and Kathleen McDill (1999). "Are All Banking Crises Alike? The Japanese Experience in International Comparison,"Journal of Japanese and International Economies (December).

Hutchison, Michael and Ilan Noy (2002). "Output Costs of Currency and Balance of Payments Crises in Emerging Markets," Comparative Economic Studies, 44(2), 27-44.

Hutchison, Michael and Ilan Noy (2005). "How Bad are Twins? Output Costs of Currency and Banking Crises". Journal of Money, Credit and Banking 37(4), 725-752.

Hutchison, Michael and Ilan Noy (2006). "Sudden Stops and the Mexican Wave: Currency Crises, Capital Flow Reversals and Output Loss in Emerging Markets. Journal of Development Economics 79(1), 225248.

Jeanne, Olivier and Ranciere, Romain (2006). The Optimal Level of International Reserves for Emerging Market Countries: Formulas and Applications. IMF Working Paper No. 06/229.

Kaminsky, Garciela (2006). "Currency crises: Are they all the same?" Journal of International Money and Finance 25, 503-527.

Kaminsky, Graciela and Carmen Reinhart (1999). "The Twin Crises. The Causes of Banking and Balanceof-Payments Problems,” American Economic Review, 89(3), 473-500.

Kiyotaki, Nobuhiro and John Moore (1997). "Credit Cycles," Journal of Political Economy 105(2), April, 211-248.

Lahiri, Amartya and Carlos A. Végh (2003). Delaying the Inevitable: Interest Rate Defense and Balance of Payments Crises. Journal of Political Economy 111(2), 404-424.

Lahiri, Amartya and Carlos A. Végh (2007). Output Costs, Currency Crises, and Interest Rate Defense of a Peg. Economic Journal 117. 
Mendoza, Enrique G. (2001). "Credit, Prices, and Crashes: Business Cycles with a Sudden Stop". NBER Working Paper 8338 (June).

Mendoza, Enrique G. and Katherine A. Smith (2006). Quantitative implications of a debt-deflation theory of Sudden Stops and asset prices. Journal of International Economics, 70(1), 82-114.

Milesi-Ferretti, Gian Maria and Assaf Razin (1998). "Sharp Reductions in current account deficits: An Empirical Analysis," European Economic Review 42, 897-908.

Milesi-Ferretti, Gian Maria and Assaf Razin (2000). "Current Account Reversals and Currency Crises: Empirical Regularities,” in Krugman, Paul (ed.) Currency Crises, Chicago, Illinois: University of Chicago Press.

Mitra, Pritha (2006). "Post-Crisis Recovery: When Does Increased Fiscal Discipline Work?” IMF working paper WP/06/219.

Mody, Ashoka and Antu Panini Murshid (2005). “Growing Up with Capital Flows." Journal of International Economics 65(1), 249-266.

Nucci, Francesco and Alberto F. Pozzolo (2001). "Investment and the Exchange Rate: An Analysis with Firm-Level Panel Data”. European Economic Review 45, 259-283.

Razin, Assaf and Efraim Sadka (2001). "Country Risk and Capital Flow Reversals", Economic Letters, 72(1), 73-77.

Razin, Assaf and Efraim Sadka (2004). “A Brazilian-Type Debt Crisis: Simple Analytics”, IMF Staff Papers, 51(1), 148-153.

Rodrik, Dani (1999). "Where Did All The Growth Go? External Shocks, Social Conflict, and Growth Collapses.” Journal of Economic Growth 4, 358-412.

Schneider, Martin and Aaron Tornell (2004). "Balance Sheet Effects, Bailout Guarantees and Financial Crises". Review of Economic Studies 71, 883-913.

Stiglitz, Joseph (1999a). "Responding to Economic Crises: Policy Alternatives for Equitable Recovery and Development." The Manchester School 67(5), 409-427.

Stiglitz, Joseph (1999b). "Begger Thyself vs. Begger-thy-neighbor: The Dangers of Intellectual Incoherence in Addressing the Global Financial Crisis." Southern Economic Journal 66(1), 1-38.

Stiglitz, Joseph (1999c). “Lessons from East Asia.” Journal of Policy Modeling 21(3), 311-330.

Stiglitz, Joseph (1999d). "Reforming the Global Economic Architecture: Lessons from Recent Crises." Journal of Finance 54(4), 1508-1521.

Tornell, Aaron and Frank Westermann (2002). "The Credit Channel in Middle Income Countries". NBER Working Paper 9355 (November). 
Table 1 Frequencies of Policy Choices and Output Outcomes in Developing and Emerging Markets

\begin{tabular}{lccc}
\hline & $\begin{array}{l}\text { Output contracted } \\
\text { following the crisis }\end{array}$ & $\begin{array}{l}\text { Output expanded } \\
\text { following crisis }\end{array}$ & All Sudden Stop crises \\
\hline \multicolumn{3}{c}{ Fiscal Policy } \\
\hline Fiscal contraction & 17 & 8 & 25 \\
Fiscal expansion & 27 & 12 & 39 \\
Total & 44 & 20 & 64 \\
\hline
\end{tabular}

\begin{tabular}{lccc}
\hline & \multicolumn{3}{c}{ Monetary Policy } \\
\hline Monetary contraction & 5 & 2 & 7 \\
Monetary expansion & 10 & 1 & 11 \\
No monetary change & 40 & 25 & 65 \\
Total & 55 & 28 & 83 \\
& & & \\
& & Exchange Policy & \\
& & & 18 \\
Reserve accumulation & 14 & 23 & 10 \\
Reserve de-cumulation & 9 & 28 & 85 \\
No reserve change & 32 & 55 & \\
Total & & & 83 \\
\hline
\end{tabular}

Note: See text (section 3) for algorithms used to identify fiscal, monetary and reserve policies pursued and for calculating the output measure (OC1) used to determine the typology above. 
Table 2 Sudden Stop Event Frequencies in Developing and Emerging Markets Economies

\begin{tabular}{lcc}
\hline & $\begin{array}{c}\text { Number } \\
\text { of events }\end{array}$ & $\begin{array}{c}\text { Frequency } \\
\text { of events } \\
(\% \text { of sample) }\end{array}$ \\
\hline $1980-1989$ & 19 & $1.29 \%$ \\
$1990-1999$ & 52 & $3.54 \%$ \\
$2000-2003$ & 31 & $5.27 \%$ \\
\hline & Degions & \\
\hline Asia & 18 & $3.00 \%$ \\
Sub-Saharan Africa & 19 & $2.47 \%$ \\
Latin America & 24 & $4.55 \%$ \\
Transition Economies & 7 & $1.62 \%$ \\
Rest of World & 34 & $2.83 \%$
\end{tabular}

This table reports the frequencies of sudden stop events across time and space. In identifying the sudden stops, we use the Honig (2005). See section 3 for more detail 
Table 3 Descriptive Statistics for Policy Variables and Macro-Controls: Developing and Emerging Market Economies

\begin{tabular}{lrrrrr}
\hline Variable & N & Mean & S.D. & MIN & MAX \\
\hline \multicolumn{7}{c}{ Output Loss Measures } \\
\hline Output cost 1 (OC1) & 83 & -9.15 & 18.68 & -81.28 & 22.38 \\
Output cost 2 (OC2) & 83 & -1.36 & 6.48 & -17.51 & 22.38 \\
Output cost 3 (OC3) & 83 & -1.71 & 5.70 & -21.07 & 16.76 \\
\hline Correlation of... & OC2 to OC3: 0.84 & OC2 to OC1: 0.68 & OC3 to OC1: 0.77 \\
\hline \multicolumn{7}{c}{ Control Variables } \\
\hline DLD & 84 & 0.13 & 0.29 & 0 & 2.22 \\
DEFCTO & 75 & 3.68 & 1.30 & 1 & 5 \\
KAOPEN & 49 & -0.25 & 1.41 & -1.84 & 2.52 \\
TRADE & 82 & 83.88 & 44.69 & 21.74 & 216.21 \\
MAJ & 83 & 0.19 & 0.40 & 0 & 1 \\
INFL & 83 & 26.11 & 82.30 & -8.62 & 693.98
\end{tabular}

See text for algorithms used to identify the output cost measures using GDP data from the World Bank's World Development Indicators. For descriptions and sources of the control variables, see appendix. 
Table $4 \quad$ Policy-only Regressions

\begin{tabular}{|c|c|c|c|c|c|}
\hline Variable & (4.1) & $(4.2)$ & (4.3) & $(4.4)$ & (4.5) \\
\hline Intercept & $\begin{array}{r}-8.34007^{\star \star \star} \\
-3.63\end{array}$ & $\begin{array}{r}-10.44701^{\star \star \star} \\
-4.30\end{array}$ & $\begin{array}{r}-7.84365^{\star \star \star} \\
-3.09\end{array}$ & $\begin{array}{r}-8.73216^{\star \star \star} \\
-3.22\end{array}$ & $\begin{array}{r}-8.02277^{\star \star} \\
-2.57\end{array}$ \\
\hline TIGHTENING & $\begin{array}{r}-10.43180^{*} \\
-1.74\end{array}$ & & & $\begin{array}{r}-13.47471^{*} \\
-1.95\end{array}$ & $\begin{array}{r}-11.27876 \\
-1.55\end{array}$ \\
\hline LOOSENING & $\begin{array}{r}2.93287 \\
0.40\end{array}$ & & & $\begin{array}{r}2.77888 \\
0.31\end{array}$ & $\begin{array}{r}4.07268 \\
0.45\end{array}$ \\
\hline DELTAD & & $\begin{array}{r}-0.14589^{\star} \\
-1.82\end{array}$ & & $\begin{array}{r}-0.15689^{*} \\
-1.98\end{array}$ & $\begin{array}{r}-0.16014^{*} \\
-1.95\end{array}$ \\
\hline RESERVED & & & $\begin{array}{r}-5.99293 \\
-0.93\end{array}$ & & $\begin{array}{r}-8.48140 \\
-1.03\end{array}$ \\
\hline RESERVEA & & & $\begin{array}{r}-2.67514 \\
-0.52 \\
\end{array}$ & & $\begin{array}{r}-0.77084 \\
-0.13 \\
\end{array}$ \\
\hline Observations & 82 & 64 & 83 & 64 & 64 \\
\hline R2 & 0.0413 & 0.0505 & 0.0121 & 0.1116 & 0.1277 \\
\hline Adjusted-R2 & 0.0170 & 0.0351 & -0.0126 & 0.0671 & 0.0525 \\
\hline F-test & 1.70 & 3.30 & 0.49 & 2.51 & 1.70 \\
\hline
\end{tabular}

Note: The table reports the change in output loss from sudden stops (dependent variable is OC1) in response to a 1 unit change in the variables with associated $\mathrm{t}$ - statistics in parentheses below. ${ }^{* * *}, * *, *$ indicate the significant level at 1,5 , and 10 percent respectively. 
Table $5 \quad$ Regressions with Policies and Controls

\begin{tabular}{|c|c|c|c|c|}
\hline Variable & (5.1) & (5.2) & (5.3) & (5.4) \\
\hline \multirow[b]{2}{*}{ Intercept } & -3.23477 & -6.27484 & -6.70754 & $-13.05922^{\star *}$ \\
\hline & -0.45 & -0.74 & -0.80 & -2.21 \\
\hline \multirow{2}{*}{ TIGHTENING } & & -11.62694 & -9.28456 & -9.99976 \\
\hline & & -1.59 & -1.26 & -1.41 \\
\hline \multirow[b]{2}{*}{ LOOSENING } & & 6.31690 & 9.86694 & 6.12802 \\
\hline & & 0.57 & 0.85 & 0.71 \\
\hline \multirow{3}{*}{ DELTAD } & & $-1.41003^{\star *}$ & $-1.89597^{\star \star *}$ & $-1.67392^{\star * \star}$ \\
\hline & & -2.33 & -2.88 & -2.81 \\
\hline & & & $-16.64839 *$ & -14.51739 \\
\hline \multirow[t]{2}{*}{ RESERVED } & & & -1.70 & -1.61 \\
\hline & & & 1.37837 & -0.00276 \\
\hline RESERVEA & & & 0.21 & -0.00 \\
\hline \multirow{2}{*}{ DEFCTO } & -2.02923 & -1.85191 & -2.36040 & \\
\hline & $\begin{array}{r}-1.16 \\
516101\end{array}$ & $\begin{array}{r}-0.92 \\
600230\end{array}$ & $\begin{array}{r}-1.13 \\
701776\end{array}$ & \\
\hline DLD & $\begin{array}{r}5.16491 \\
0.65\end{array}$ & $\begin{array}{r}6.88238 \\
0.82\end{array}$ & $\begin{array}{r}7.84776 \\
0.95\end{array}$ & \\
\hline \multirow{2}{*}{ TRADE } & 0.02364 & 0.02875 & 0.04793 & 0.05001 \\
\hline & 0.43 & 0.46 & 0.77 & 0.95 \\
\hline \multirow[b]{2}{*}{ MAJ } & $-12.43582^{\star \star}$ & -9.70189 & -3.41089 & -5.25368 \\
\hline & -2.21 & -1.44 & -0.45 & -0.79 \\
\hline \multirow[b]{2}{*}{ INFLATION } & & 0.08388 & 0.08470 & 0.10578 \\
\hline & & 0.85 & 0.87 & 1.13 \\
\hline Observations & 67 & 54 & 54 & 63 \\
\hline R2 & 0.1653 & 0.2796 & 0.3303 & 0.2581 \\
\hline Adjusted-R2 & 0.0968 & 0.1516 & 0.1746 & 0.1482 \\
\hline F-test & 2.42 & 2.18 & 2.12 & 2.35 \\
\hline
\end{tabular}

Note: The table reports the change in output loss from sudden stops (dependent variable is OC1) in response to a 1 unit change in the variables with associated t- statistics in parentheses below. $* * * * * *$ indicate the significant level at 1,5 , and 10 percent respectively. 
Table 6 Tight Policy Regressions

\begin{tabular}{|c|c|c|c|}
\hline Variable & (6.1) & (6.2) & (6.3) \\
\hline Intercept & $\begin{array}{r}-7.8704^{\star \star *} \\
-2.99\end{array}$ & $\begin{array}{r}-6.00057 \\
-0.73\end{array}$ & $\begin{array}{r}-12.37911^{* *} \\
-2.45\end{array}$ \\
\hline TIGHTENING & $\begin{array}{r}-11.72160 \\
-1.65\end{array}$ & $\begin{array}{r}-10.48243 \\
-1.47\end{array}$ & $\begin{array}{r}-14.34684^{\star *} \\
-2.60\end{array}$ \\
\hline DELTAD & $\begin{array}{r}-0.16385^{\star \star} \\
-2.08\end{array}$ & $\begin{array}{r}-1.84710^{\star \star \star} \\
-2.86\end{array}$ & $\begin{array}{r}-1.91266^{\star \star \star} \\
-3.69\end{array}$ \\
\hline RESERVED & $\begin{array}{r}-7.87254 \\
-1.00\end{array}$ & $\begin{array}{r}-15.21699 \\
-1.65\end{array}$ & $\begin{array}{r}-21.56279^{\star *} \\
-2.70\end{array}$ \\
\hline TRADE & & $\begin{array}{r}0.04281 \\
0.70\end{array}$ & $\begin{array}{r}0.07381 \\
1.59\end{array}$ \\
\hline MAJ & & $\begin{array}{r}-3.69035 \\
-0.50\end{array}$ & $\begin{array}{r}-6.51561 \\
-1.18\end{array}$ \\
\hline INFLATION & & $\begin{array}{r}0.08181 \\
0.85\end{array}$ & $\begin{array}{r}0.12635 \\
1.14\end{array}$ \\
\hline $\begin{array}{l}\text { KAOPEN*TRAD } \\
\text { E }\end{array}$ & & & $\begin{array}{r}-0.03012 \\
-1.57\end{array}$ \\
\hline Observations & 64 & 54 & 46 \\
\hline R2 & 0.1246 & 0.3159 & 0.5452 \\
\hline Adjusted-R2 & 0.0808 & 0.1943 & 0.4614 \\
\hline F-test & 2.85 & 2.60 & 6.51 \\
\hline
\end{tabular}




\section{Appendix A Data Sources and Definitions}

\section{Output Cost 1 definition (OC1):}

OC1 is constructed by comparing, in real terms, the pre-crisis GDP growth rate of a certain country with the GDP growth rate during the following years until the pre-crisis rate is reached. This approach considers pre-crisis GDP growth rates to be the trend or a country's potential growth rates. The pre-crisis GDP growth is calculated as the average of GDP growth rates from year $t-3$ to $t-1$, where year $t$ is the start of the crisis. Then, each GDP growth rate from year $t$ onwards is compared to the trend until the trend growth is reached. The output loss is defined as the sum of the difference between the actual and the trend growth rate over all the years until the trend growth is reached again.

\section{Variables used to construct the dependent and macroeconomic policy variables:}

- Annual real GDP growth

- Monthly non-gold reserves, US dollar

- Monthly discount rate, \% per year, end of period

- Annual budget balance (\% of GDP)

\section{Control variables:}

- Foreign liabilities (\% of GDP)

- Trade openness:

Exports and Imports (\% of GDP)

- Inflation rate

- Banking crises

- Capital account liberalization index

- De-facto exchange rate regime
WDI, NY.GDP.MKTP.KD.ZG

IFS, Line 11.d

IFS, Line 60

WDI, GB.BAL.OVRL.GD.ZS
DLD IFS, Line 26c

TRADE WDI, NE.EXP.GNFS.ZS

WDI, NE.IMP.GNFS.ZS

INFL WDI, FP.CPI.TOTL.ZG

MAJ Hutchison \& Noy, 2005

KAOPEN Chinn \& Ito, 2005

DEFCTO Levy-Yeyati \& Sturzennegger, 2002 
Appendix B Sudden Stop episodes in non-OECD countries (Honig definition)

\begin{tabular}{|c|c|c|c|c|c|}
\hline Albania & 1990 & 1995 & Indonesia & 1997 & \\
\hline Algeria & 1990 & & Iran, I.R. of & 1999 & \\
\hline Angola & 2000 & & Israel & 1988 & 1998 \\
\hline Antigua and Barbuda & 1998 & & Jamaica & 2002 & \\
\hline Argentina & 2001 & & Jordan & 1992 & \\
\hline Barbados & 1982 & 2002 & Macedonia, FYR & 1999 & \\
\hline Bolivia & 1982 & & Malaysia & 1994 & 1997 \\
\hline Botswana & 1993 & & Malta & 1995 & 2000 \\
\hline Brazil & 2002 & & Mauritius & 2001 & \\
\hline Cameroon & 1988 & & Moldova & 1995 & \\
\hline Cape Verde & 1990 & 2000 & Mongolia & 1990 & \\
\hline Chile & 1982 & 1998 & Morocco & 1995 & \\
\hline China,P.R.: Mainland & 1998 & & Nicaragua & 1986 & \\
\hline Colombia & 1998 & & Oman & 1987 & 1999 \\
\hline Comoros & 1988 & & Pakistan & 1998 & \\
\hline Costa Rica & 1996 & 2000 & Panama & 2000 & \\
\hline Cyprus & 1998 & & Peru & 1983 & 1998 \\
\hline Dominica & 1996 & 2001 & Philippines & 1997 & \\
\hline Dominican Republic & 2002 & & Poland & 1994 & 2001 \\
\hline Ecuador & 1983 & 1999 & Solomon Islands & 1998 & \\
\hline Egypt & 1990 & & South Africa & 2000 & \\
\hline El Salvador & 1999 & & St. Vincent \& Grens. & 1999 & 2002 \\
\hline Fiji & 1999 & & Swaziland & 1999 & \\
\hline Gabon & 1989 & & Syrian Arab Republic & 1989 & \\
\hline Gambia, The & 1982 & & Thailand & 1997 & \\
\hline Ghana & 2000 & & Tonga & 1985 & 1989 \\
\hline Grenada & 1999 & & Trinidad and Tob. & 1984 & \\
\hline Guinea & 1989 & & Tunisia & 2000 & \\
\hline Guyana & 1995 & & Ukraine & 1998 & \\
\hline Haiti & 1999 & 2002 & Uruguay & 2002 & \\
\hline Honduras & 2000 & & Vanuatu & 1991 & \\
\hline Hungary & 1996 & & Venezuela & 1994 & \\
\hline India & 1995 & & Zimbabwe & 1983 & 1994 \\
\hline
\end{tabular}




\section{Footnotes}

${ }^{1}$ See table 3 for details on this measure of output cost. See also Hutchison and Noy (2006) for another measure of the output cost of sudden stops (of $13-15 \%$ of GDP).

${ }^{2}$ In previous work, Lahiri and Végh (2003) examined the impact of an interest rate defense on crisis timing.

${ }^{3}$ Cúrdia (2007), in a theoretical paper, also examines the impact of various monetary policy rules on the consequences of sudden stops.

${ }^{4}$ In stark contrast, Chari et al. (2005) argue, based on a general equilibrium model, that sudden stops are expansionary and the reduction of output observed in recent crises is due to other financial frictions that overwhelm the positive effect of sudden stops.

${ }^{5}$ If the crises for a country are very close (less than 3 years apart), we ignore the second crisis and only include the first crisis in our sample to calculate output loss. For Cavallo's (2004) Sudden stop episodes, Cameroon 1990, Chile 1983, Colombia 1999, Jordan 1993, Mexico 1995, and Mongolia 1991 are dropped out of our sample. If the crises for a country are 3 years apart, we use the pre-first-crisis trend as the trend growth for the second crisis in calculating output loss.

${ }^{6}$ Since we are attempting to explain the wide range of output paths following sudden stops, dropping the output contraction condition appears justifies.

${ }^{7}$ For the developing countries' cases, the only case in which the classification was not straightforward was Turkey (1994).

${ }^{8}$ Using a binary measure goes some way toward accounting for a possible endogeneity of the monetary policy decision. We suspect that while the magnitude of the monetary reaction might depend on output developments, that is most likely not the case for the direction of that policy.

${ }^{9}$ Those country/years are: Israel (1988), Mexico (1995), Thailand (1997), Turkey (1994), and Venezuela (1994).

${ }^{10}$ Those country/years are: Algeria (1990), Barbados (1982), Chile (1983), Costa Rica (1981), and Egypt (1990).

${ }^{11}$ We obtained an initial list of control variables based on earlier literature, in particular the specifications in Calvo et al. (2004). We narrow this list of controls based on the benchmark regression statistics. In a previous version of the paper we also used total debt service (\% of exports) and a government stability index. The inclusion of these variables does not change any of our main results.

${ }^{12}$ All the results reported in the last three paragraphs are available from the corresponding author upon request. 